\title{
The relationship between corporate governance and foreign ownership of the banks in developing countries
}

\section{La relación entre gobierno corporativo y propiedad extranjera de los bancos en los países en desarrollo}

\author{
K. Batu Tunay ${ }^{\mathrm{a}, *}$, Serhat Yüksel ${ }^{\mathrm{b}}$ \\ a Marmara University, Turkey \\ b Istanbul Medipol University, Turkey
}

Received 15 December 2016; accepted 29 May 2017

Available online 2 November 2017

\begin{abstract}
The aim of this paper is to determine the effect of corporate governance on foreign ownership of the banks. Within this context, annual data of 65 developing countries for the periods between 2004 and 2013 was analyzed. In addition to this situation, 7 explanatory variables were used in this study in order to achieve this objective. As a result of the analysis, it was identified that there is a strong relationship between operations of foreign banks and governance levels of the countries. In this regard, it was determined that the factors of corruption, political stability, rule of law and flexibility in legal regulations affect foreign bank operations. Moreover, it was also analyzed that foreign bank operations are stronger in the countries that have low poverty, high political stability and efficient legal infrastructure. On the other hand, it was defined that strict legal regulation affects foreign bank operations negatively which shows that foreign banks prefer to enter into the countries that have flexible legal regulations. This study gives essential information to developing countries about the factors that affect the decisions of foreign banks in order to enter into a developing country. Therefore, by considering the results of this study, the authorities of these countries can have a chance to take necessary actions so as to attract foreign banks.

(C) 2017 Universidad Nacional Autónoma de México, Facultad de Contaduría y Administración. This is an open access article under the CC BY-NC-ND license (http://creativecommons.org/licenses/by-nc-nd/4.0/).
\end{abstract}

JEL classification: G21; G28; G34; G38

Keywords: Banking; Corporate governance; Foreign banks

\footnotetext{
* Corresponding author.

E-mail address: batu.tunay@ marmara.edu.tr (K.B. Tunay).

Peer Review under the responsibility of Universidad Nacional Autónoma de México.
} 


\section{Resumen}

El objetivo de este trabajo es determinar el efecto del gobierno corporativo sobre la propiedad extranjera de los bancos. En este contexto, se analizaron los datos anuales de 65 países en desarrollo de los períodos comprendidos entre 2004 y 2013. Además de esta situación, se utilizaron 7 variables explicativas para alcanzar este objetivo. Como resultado del análisis, se identificó que existe una relación fuerte entre las operaciones de los bancos extranjeros y los niveles de gobierno de los países. A este respecto, se determinó que los factores de corrupción, estabilidad política, estado de derecho y flexibilidad en las regulaciones legales afectan a las operaciones de los bancos extranjeros. Además, se analizó que las operaciones de bancos extranjeros son más fuertes en los países que tienen baja pobreza, alta estabilidad política y una eficiente infraestructura jurídica. Por otra parte, se definió que una estricta regulación legal afecta negativamente a las operaciones de los bancos extranjeros, lo que muestra que los bancos extranjeros prefieren entrar en los países que tienen regulaciones legales flexibles. Este estudio proporciona información esencial a los países en desarrollo sobre los factores que afectan las decisiones de los bancos extranjeros antes de entrar en un país en desarrollo. Por consiguiente, al considerar los resultados de este estudio, las autoridades de estos países pueden tener la oportunidad de adoptar las medidas necesarias para que atraigan bancos extranjeros. (C) 2017 Universidad Nacional Autónoma de México, Facultad de Contaduría y Administración. Este es un artículo Open Access bajo la licencia CC BY-NC-ND (http://creativecommons.org/licenses/by-nc-nd/4.0/).

Códigos JEL: G21; G28; G34; G38

Palabras clave: Banca; Gobierno corporativo; Bancos extranjeros

\section{Introduction}

Corporate governance means the processes and relations that are controlled by the companies (Shailer, 2004). In addition to this definition, in banking sector, corporate governance refers to the purposes, regulations and strategies which are directed by the top management of the bank. The main purpose of corporate governance is to satisfy the demands of the shareholders. Owing to this issue, companies will be more transparent and people will have more confidence to them. Moreover, this situation also leads to increase in the performance of the companies (Barakat \& Hussainey, 2013).

In addition to the companies, corporate governance is also significant for the countries. With respect to higher corporate governance, political intervention is expected to be at the minimum level in the country. Therefore, transparency can be increased it this country (Ho, Lin, \& Tsai, 2015). Otherwise, the political and economical stability cannot be obtained. Due to this problem, foreign investors become reluctant to enter this country.

Furthermore, it was thought that there is a relationship between corporate governance levels and foreign ownership of the banks. According to the empirical studies, this relationship has two ways. Firstly, it was defined that foreign banks prefer to enter into the countries that have high corporate governance levels. Similar to this situation, it was also determined that foreign banks increase the corporate governance levels of the countries in which they operate.

When taking into the consideration of these factors, in this paper, we tried to understand the relationship between corporate governance and foreign ownership of the banks. In order to achieve this objective, we made a panel data analysis to 65 developing countries. By making this analysis, it will be possible to define the effect of corporate governance on foreign ownership of the banks. The paper is organized as follows: in the second part, we give general information about 
similar studies. Also, the third part includes research and application to understand the relationship between corporate governance and foreign ownership of the banks. Finally, the analyze results were given at conclusion.

\section{Literature review}

There is an increase in the number of the studies related to the corporate governance in the literature in recent years. One of the main reasons behind this situation is the global economic crisis which was occurred in USA in 2008 and spread to many developed and developing countries. Some of these studies are depicted in Table 1.

Table 1 shows that a lot of studies tried to evaluate the relationship between corporate governance and CEO compensation. For instance, Acrey, McCumber, and Nguyen (2011) analyzed this relationship and concluded that this compensation increases the risks for the banks. Özelge and Saunders (2012), Li and Song (2013), Oh, Park, and Ghauri (2013), Anginer et al. (2016) reached the similar results in their studies. On the other hand, Fahlenbrach and Stulz (2011) concluded that there is not such a negative relationship between them.

Drew, Kelley, and Kendrick (2006) and Aebi, Sabato, and Schmid (2012) reached a conclusion that effective risk management and corporate governance are associated with higher performance for the banks. Nonetheless, Iqbal, Strobl, and Vahamaa (2015) stated that there is a positive relationship between corporate governance and systematic risk. Furthermore, Qian and Yeung (2015) analyzed the relationship between bank financing and corporate governance whereas Barakat and Hussainey (2013) and Masciandaro, Pansini, and Quintyn (2013) emphasized the importance of bank regulation and supervision.

In spite of these studies in which the role of the governance for the banks was analyzed in different situation, there are a few studies that emphasized the governance of the countries that banks located. Cull, Li, Sun, and Xu (2015) identified that the firms, which have a close connection with Chinese government, are subject to less limitations. It was also determined that this situation directly affects the financing conditions of these firms. The main reason behind this situation is that loan allocation process will be degenerated due to the fact that some firms can obtain finance from the state banks easily. It can also be said that this issue will decrease the portfolio quality of Chinese banks. Similar to this study, Lin, Ho, Shen, and Wang (2016) reached the conclusion that during the election period in Taiwan, there is a significant increase in the stock values of the firms that have a close relationship with the government.

In addition to these studies, Shen, Lin, and Wang (2015) defined that there is an inverse relationship between corporate governance and political relationship with the government in Taiwan by using panel data analysis method. Chiatan (2012) also reached the similar results for Romania by using the same method. Additionally, Jackowicz, Kowalewski, and Kozlowski (2013) examined the effects of political factors on the performance of commercial banks in 11 European countries. They demonstrated that there is a decline in the performance of state banks owing to the decreasing the interest rate irrationally during the election period. In parallel with these studies, Barry, Lepetit, and Strobel (2015) and Chen, Jeon, Wang, and Wu (2015) also defined that corruption in state banks is higher than the other types of the banks.

In the literature, there are also some studies that focused on the relationship between corporate governance and foreign ownership of the banks. The common result of these studies is that foreign ownership of the banks increases corporate governance. Chen and Liao (2011) analyzed the profitability of foreign and domestic banks in 70 different countries. They concluded that foreign banks that operate in the countries in which the ratio of regularity compliance is high have 
Table 1

Studies related to corporate governance.

\begin{tabular}{|c|c|c|c|}
\hline Author & Method & Determinants & Results \\
\hline $\begin{array}{l}\text { Drew et al. } \\
\qquad(2006)\end{array}$ & $\begin{array}{l}\text { Descriptive } \\
\text { Statistics }\end{array}$ & $\begin{array}{l}\text { Culture, leadership, alignment, } \\
\text { systems, structure }\end{array}$ & $\begin{array}{l}\text { They concluded that effective risk } \\
\text { management is one of the main } \\
\text { sources of competitive advantages } \\
\text { for the firms. }\end{array}$ \\
\hline $\begin{array}{l}\text { Acrey et al. } \\
\quad(2011)\end{array}$ & Regression & $\begin{array}{l}\text { CEO compensation, age of the } \\
\text { executive, number of years as } \\
\text { CEO, natural log of total firm } \\
\text { assets }\end{array}$ & $\begin{array}{l}\text { It was defined that CEO } \\
\text { compensation increases bank } \\
\text { default risk }\end{array}$ \\
\hline $\begin{array}{l}\text { Chen and Liao } \\
\text { (2011) }\end{array}$ & Regression & $\begin{array}{l}\text { Net interest margin, ROA, ROE, } \\
\text { capital, total assets, operational } \\
\text { cost, liquidity, non-interest } \\
\text { revenues, off-balance sheet items, } \\
\text { market share }\end{array}$ & $\begin{array}{l}\text { It was identified that when foreign } \\
\text { banks operate in a host country } \\
\text { with stricter regulatory compliance, } \\
\text { the margin of these banks increases. }\end{array}$ \\
\hline $\begin{array}{l}\text { Fahlenbrach } \\
\text { and Stulz } \\
\text { (2011) }\end{array}$ & Regression & $\begin{array}{l}\text { Cash bonus/salary, ROA, ROE, } \\
\text { equity risk, log of market value, } \\
\text { capital adequacy ratio }\end{array}$ & $\begin{array}{l}\text { They concluded that banks, which } \\
\text { gave large amount of cash bonuses } \\
\text { to their CEOs, did not perform } \\
\text { worse during the crisis period. }\end{array}$ \\
\hline $\begin{array}{l}\text { Aebi et al. } \\
\quad(2012)\end{array}$ & $\begin{array}{l}\text { Panel data } \\
\text { analysis }\end{array}$ & $\begin{array}{l}\text { ROE, ROA, total assets, board } \\
\text { size, board independence, } \\
\text { loans/assets, capital adequacy } \\
\text { ratio }\end{array}$ & $\begin{array}{l}\text { It was determined that banks, which } \\
\text { have efficient corporate governance } \\
\text { and risk management system, have } \\
\text { higher performance in crisis period. }\end{array}$ \\
\hline $\begin{array}{l}\text { Özelge and } \\
\text { Saunders } \\
(2012)\end{array}$ & Probit & $\begin{array}{l}\text { Stock performance, return on } \\
\text { assets, total loans, number of } \\
\text { turnovers }\end{array}$ & $\begin{array}{l}\text { Banks have a significant role on } \\
\text { CEO turnovers of the firms that } \\
\text { used high amount of loans. }\end{array}$ \\
\hline Chitan (2012) & Regression & $\begin{array}{l}\text { ROA, ROE, total loans to private } \\
\text { sector, capital regulations, total } \\
\text { deposits, liquidity ratio }\end{array}$ & $\begin{array}{l}\text { It was identified that higher } \\
\text { corporate governance leads to } \\
\text { increase the performance of the } \\
\text { banks. }\end{array}$ \\
\hline $\begin{array}{l}\text { Chaigneau } \\
\text { (2013) }\end{array}$ & $\begin{array}{l}\text { Descriptive } \\
\text { Statistics }\end{array}$ & $\begin{array}{l}\text { CEO's pay, CEO's effort, cost of } \\
\text { effort, bank assets, bank value, }\end{array}$ & $\begin{array}{l}\text { It was determined that current } \\
\text { corporate governance arrangements } \\
\text { in the banking sector are not } \\
\text { efficient. }\end{array}$ \\
\hline $\begin{array}{l}\mathrm{Li} \text { and Song } \\
\text { (2013) }\end{array}$ & $\begin{array}{l}\text { Panel data } \\
\text { analysis }\end{array}$ & $\begin{array}{l}\text { Total assets, capital-asset ratio, } \\
\text { loan-asset ratio, ownership } \\
\text { concentration, loan loss provision } \\
\text { ratio, liquidity ratio, cost to } \\
\text { income ratio }\end{array}$ & $\begin{array}{l}\text { It was defined that legal system } \\
\text { with better investor rights } \\
\text { protection and better contracts } \\
\text { enforcement increases board } \\
\text { independence. }\end{array}$ \\
\hline $\begin{array}{l}\text { Jackowicz } \\
\text { et al. (2013) }\end{array}$ & Regression & $\begin{array}{l}\text { GDP, inflation, M2, net } \\
\text { commission income, total assets, } \\
\text { total loans, equity }\end{array}$ & $\begin{array}{l}\text { It was determined that state-owned } \\
\text { banks in Europe have smaller net } \\
\text { interest income ratios during the } \\
\text { years of parliamentary elections. }\end{array}$ \\
\hline $\begin{array}{l}\text { Masciandaro } \\
\text { et al. (2013) }\end{array}$ & Regression & $\begin{array}{l}\text { The degree of central bank } \\
\text { involvement, GDP growth, total } \\
\text { assets, the log of population }\end{array}$ & $\begin{array}{l}\text { It was identified that supervisory } \\
\text { governance is negatively correlated } \\
\text { with economic resilience. }\end{array}$ \\
\hline $\begin{array}{l}\text { Barakat and } \\
\text { Hussainey } \\
\text { (2013) }\end{array}$ & $\begin{array}{l}\text { Panel data } \\
\text { analysis }\end{array}$ & $\begin{array}{l}\text { GDP per capita, inflation, total } \\
\text { assets, political stability, cash } \\
\text { deposits, government ownership }\end{array}$ & $\begin{array}{l}\text { They reached a conclusion that } \\
\text { banks having a higher proportion of } \\
\text { outside board directors provide } \\
\text { operational risk disclosure of } \\
\text { higher quality. }\end{array}$ \\
\hline
\end{tabular}


Table 1 (Continued)

\begin{tabular}{|c|c|c|c|}
\hline Author & Method & Determinants & Results \\
\hline $\begin{array}{l}\text { Oh et al. } \\
\text { (2013) }\end{array}$ & Survey & $\begin{array}{l}\text { Anti-crime policy/measure, brand } \\
\text { management, corporate } \\
\text { governance, customer } \\
\text { relationship management, } \\
\text { research and development, } \\
\text { stakeholder engagement }\end{array}$ & $\begin{array}{l}\text { It was concluded that corporate } \\
\text { social responsibility is an important } \\
\text { factor in order to increase the } \\
\text { performance. }\end{array}$ \\
\hline $\begin{array}{l}\text { Iqbal et al. } \\
\text { (2015) }\end{array}$ & Regression & $\begin{array}{l}\text { Non-interest income, deposits to } \\
\text { assets, loan growth, loans to } \\
\text { assets, ROA, capital ratio, total } \\
\text { assets }\end{array}$ & $\begin{array}{l}\text { They concluded that financial } \\
\text { institutions with stronger corporate } \\
\text { governance are associated with } \\
\text { higher levels of systemic risk. }\end{array}$ \\
\hline $\begin{array}{r}\text { Qian and } \\
\text { Yeung } \\
(2015)\end{array}$ & $\begin{array}{l}\text { Panel data } \\
\text { analysis }\end{array}$ & $\begin{array}{l}\text { ROA, ROE, EBITDA, other } \\
\text { receivables, total assets, sales } \\
\text { growth }\end{array}$ & $\begin{array}{l}\text { It was concluded that inefficient } \\
\text { bank financing leads to weak } \\
\text { corporate governance. }\end{array}$ \\
\hline $\begin{array}{l}\text { Cull et al. } \\
\text { (2015) }\end{array}$ & Tobit & $\begin{array}{l}\text { GDP per capita, the age of the } \\
\text { firm, sales, total loans, CEO wage }\end{array}$ & $\begin{array}{l}\text { They concluded that investment in } \\
\text { firms with strong government } \\
\text { connections is less sensitive to } \\
\text { internal cash flows in China. }\end{array}$ \\
\hline $\begin{array}{l}\text { Zagorchev and } \\
\text { Gao (2015) }\end{array}$ & $\begin{array}{l}\text { Multivariate } \\
\text { PANEL } \\
\text { models }\end{array}$ & $\begin{array}{l}\text { Corporate governance vector, } \\
\text { Earnings before tax, loan loss } \\
\text { provision, total assets, liquid } \\
\text { assets, dividends, total deposits }\end{array}$ & $\begin{array}{l}\text { It was determined that better } \\
\text { corporate governance is associated } \\
\text { with less total non-performing } \\
\text { assets. }\end{array}$ \\
\hline $\begin{array}{l}\text { Barry et al. } \\
\quad(2015)\end{array}$ & Probit & $\begin{array}{l}\text { Lending corruption, bank } \\
\text { ownership, firm control, country } \\
\text { control, number of competitors, } \\
\text { sales, GDP growth, inflation }\end{array}$ & $\begin{array}{l}\text { It was identified that when } \\
\text { state-owned banks or family-owned } \\
\text { banks provide a higher proportion } \\
\text { of credit to the economy, } \\
\text { corruption is higher. }\end{array}$ \\
\hline Luo (2015) & GMM & $\begin{array}{l}\text { ROA, size of the bank, leverage } \\
\text { ratio, annual stock return, bank } \\
\text { ownership, CEO share }\end{array}$ & $\begin{array}{l}\text { The results show that there is no } \\
\text { significant relationship between } \\
\text { bank performance and executive } \\
\text { compensation in Chinese banking } \\
\text { sector }\end{array}$ \\
\hline $\begin{array}{l}\text { Chen et al. } \\
\text { (2015) }\end{array}$ & Regression & $\begin{array}{l}\text { ROA, logarithm of assets, The } \\
\text { ratio of liquid assets to total } \\
\text { assets, The ratio of overhead cost } \\
\text { to the sum of net interest revenue } \\
\text { and non-interest income }\end{array}$ & $\begin{array}{l}\text { It was concluded that higher levels } \\
\text { of corruption increase the } \\
\text { risk-taking behavior of banks. }\end{array}$ \\
\hline $\begin{array}{l}\text { Ho et al. } \\
\qquad(2015)\end{array}$ & Logit & $\begin{array}{l}\text { Total assets, total equity, total } \\
\text { loans, total deposits, ROA, total } \\
\text { debts to total equities, GDP, } \\
\text { budget surplus, inflation, } \\
\text { exchange rate }\end{array}$ & $\begin{array}{l}\text { It was determined that country } \\
\text { governance reduces privatization } \\
\text { effects in developing countries. }\end{array}$ \\
\hline $\begin{array}{l}\text { Min and } \\
\text { Bowman } \\
(2015)\end{array}$ & $\begin{array}{l}\text { Panel data } \\
\text { analysis }\end{array}$ & $\begin{array}{l}\text { Dividend, current ratio, liquidity, } \\
\text { foreign ownership, short term } \\
\text { financial distress }\end{array}$ & $\begin{array}{l}\text { It was determined that there is a } \\
\text { positive relationship between } \\
\text { foreign ownership and corporate } \\
\text { governance. }\end{array}$ \\
\hline $\begin{array}{l}\text { Shen et al. } \\
\quad(2015)\end{array}$ & $\begin{array}{l}\text { Panel data } \\
\text { analysis }\end{array}$ & $\begin{array}{l}\text { Total assets, Profitability, } \\
\text { Leverage Ratio, Tangibility }\end{array}$ & $\begin{array}{l}\text { They concluded that firms with } \\
\text { higher corporate governance focus } \\
\text { less on political connection. }\end{array}$ \\
\hline
\end{tabular}


Table 1 (Continued)

\begin{tabular}{|c|c|c|c|}
\hline Author & Method & Determinants & Results \\
\hline $\begin{array}{l}\text { Anginer, } \\
\text { Demirguc- } \\
\text { Kunt, } \\
\text { Huizinga, } \\
\text { and Ma } \\
(2016)\end{array}$ & Regression & $\begin{array}{l}\text { Capital, market value, board } \\
\text { independence, board size, CEO } \\
\text { total compensation, CEO shares, } \\
\text { ROA, total assets }\end{array}$ & $\begin{array}{l}\text { It was defined that there is a } \\
\text { negative relationship between good } \\
\text { corporate governance and bank } \\
\text { capitalization }\end{array}$ \\
\hline $\begin{array}{l}\text { Lassoued et al. } \\
\qquad(2016)\end{array}$ & Regression & $\begin{array}{l}\text { ROA, loan loss provision, capital } \\
\text { adequacy ratio, total assets, fixed } \\
\text { assets, loan to deposit ratio }\end{array}$ & $\begin{array}{l}\text { They concluded that state banks } \\
\text { take higher risk by comparing with } \\
\text { foreign banks. }\end{array}$ \\
\hline $\begin{array}{l}\text { Lin et al. } \\
(2016)\end{array}$ & Regression & $\begin{array}{l}\text { Cumulated abnormal returns, } \\
\text { ROA, the investment to total } \\
\text { assets ratio, the logarithm of the } \\
\text { last year-end market value of } \\
\text { outstanding shares of each firm, } \\
\text { cash and cash equivalence }\end{array}$ & $\begin{array}{l}\text { It was identified that both political } \\
\text { connection and government policy } \\
\text { affect stock returns in Taiwan. }\end{array}$ \\
\hline
\end{tabular}

better performance than other banks. Luo (2015) also emphasized that managers in state banks are not independent to give decisions where there is not such a problem in foreign banks.

Min and Bowman (2015) also analyzed the corporate governance in South Korea after the crisis occurred in 1997. They reached a conclusion that foreign banks give importance to the independent managers at the bank. Similarly, Lassoued, Sassi, and Attia (2016) identified that foreign banks takes lower risks although state banks have the tendency to take higher risks. Moreover, Ho et al. (2015) examined the privatization process of 113 state banks in 39 different countries for the periods between 1996 and 2007. They also tried to analyze the relationship between this process and corporate governance. As a result of this study, it was defined that after privatization, there is an increase in the performance of the banks especially in developing countries. This situation shows that owing to the privatization, political intervention to the banks can be minimized.

As it can be seen from Table 1, there are lots of studies in the literature which analyzed the corporate governance. These studies focused on the effects of corporate governance on many different aspects, such as the performance of the companies and economic growth of the country. However, there are only a few studies which emphasized the importance of corporate governance levels of the countries for the decisions of the investors. In addition to this situation, these few studies focused on the conditions in only one or two countries. Owing to this issue, it can be said that a study, which examines the situation in a large number of countries, will contribute very much to the literature.

\section{Empirical analysis}

\section{Analysis method}

Empirical studies, which evaluate governance, generally focus on the performance and the stability in banking sector. It was identified that the type of the ownership has a significant effect on bank performance. The main reason behind this aspect is that bank shareholders, who hold the ownership control, have the power to maintain their own corporate governance mindset. Within this scope, it is observed that foreign banks want to evaluate profitable investment opportunities in local banking markets, but cultural factors are influential in this situation. It is identified that 
banks are more successful in local markets with high cultural proximity (Clarke, Cull, Martinez Peria, \& Sánchez, 2001). Foreign banks are mainly focused on corporate banking activities in the countries where they operate. Nevertheless, Berger, Klapper, and Udell (2000) found that when there is a strong cultural tie between the original country of the bank with the country where this bank operates, it will finance small businesses much more than the others. Additionally, similar cultural features are also influential in the foreign market entry strategies that depend on purchasing local banks because cultural intimacy encourages foreign banks to buy local banks (Clarke et al., 2001).

Arun and Turner (2004) argued that increasing levels of competition in the developing world as foreign banks enter the market will improve the institutional governance of the banking system. These ideas are based on the views of Demirguc-Kunt and Detragiache (1998), Levine (1999), Claessens, Demirguc-Kunt, and Huizinga (1998), Claessens, Demirguc-Kunt, and Huizanga (2000) and Peek and Rosengren (2000). These studies show that foreign banking entries in emerging economies increase competition in the banking sector and this issue encourages the banks to implement new methods which improve the corporate governance. Furthermore, the presence of foreign banks in the system causes the local banks to be more cautious about taking risks and this decreases the possibility of fragility and crisis (Arun \& Turner, 2004; Caprio \& Levine, 2002; Levine, 2004).

Lensink, Meesters, and Naaborg (2008) showed that the effectiveness of foreign banking activities increased when the governance level difference between host country and the country where the center of the foreign bank is located is small. This finding suggests that foreign banks will prefer to the countries which have high level of corporate governance. However, as Miklaszewska and Mikolajczyk (2011) have pointed out that foreign banks aim not only for efficiency but also for profitability and significant profit opportunities to the emerging economies. The main reason for this aspect is that they can have a chance to increase market share quickly in these countries.

Miklaszewska and Mikolajczyk (2011) have examined the influence of foreign bank governance level on the performance in some emerging European countries. In the models they analyze, the level of governance in the home country is considered as one of the variables that explain the performance. Findings have shown that high earnings opportunities are a major factor in foreign bank entry. Many foreign banks are following risky strategies. However, it was identified that some foreign banks give more importance to the efficiency more than profitability. For instance, German, Austrian, Belgian and Dutch banks pay less attention to efficiency, while the US, Italian and French banks attach great importance to this aspect. On the other hand, the most important finding is that governance has positively influenced overall bank performance. This finding indicates that foreign banks have given importance to the governance model of the country in which they operate.

While considering these issues, it can be said that governance has significant effects on foreign banking activities in developing countries. Because corporate governance affects efficiency, effectiveness and profitability positively according to some studies, foreign banks consider this situation for the countries where they will operate. This study aims to examine the validity of the acceptance that foreign banks are affected by corporate governance levels in developing countries. Within this scope, it was assumed that governance level of the developing countries is significant for the entry decision and operating volumes of the foreign banks in these countries. Owing to this situation, following model was created with the pre-acceptance that the number of foreign banks is high and total assets of these banks is higher than the others in the countries which have high governance levels. 


$$
F B_{i t}=a+\sum_{j=1}^{p} \lambda_{j} F B_{i t-j}+B C G_{i t}+\varepsilon_{i t}
$$

In Eq. (1), " $F B$ " represents the vectors of dependent variables. It consists of two alternative variables which are the ratio of foreign banks to total banks $(F B / T B)$ in country " $i$ " at time " $t$ " and the ratio of total assets of foreign banks to the total assets of total banks (TA $/ T A)$. Moreover, " $C G_{i t} t^{\prime}$ represents the vectors of the variables that show corporate governance levels in country " $i$ " at time " $t$ " and " $B$ " refers to the vectors of the parameters for these variables:

$$
C G_{i t}=\left\{C o C_{i t}, G E_{i t}, P S A V_{i t}, R Q_{i t}, R o L_{i t}, V A_{i t}\right\}
$$

In Eq. (2), " $C o C_{i t}$ " shows control of corruption whereas " $G E_{i t}$ " refers to the government effectiveness. Furthermore, " $P S A V_{i t}$ " means political stability and absence of violence and " $R Q_{i t}$ " explains regularity quality. In addition to them, "RoLit" demonstrates the rule of law and "VA refers to the voice and accountability. Increase in these variables means that governance levels will go up in this country and it plays an important role in the development of foreign banks activity according to our fundamental assumption. Therefore, it was estimated that these variables affect the dependent variables positively. The parameter vectors for governance variables can be defined as $B=\left\{\beta_{1}, \ldots, \beta_{6}\right\}$.

In this study, following two parametric models will be analyzed with respect to the alternative independent variables:

$$
\begin{aligned}
(F B / T B)_{i t} & =\alpha+\sum_{j=1}^{p} \lambda_{j}(F B / T B)_{i t-j}+\beta_{1} C o C_{i t}+\beta_{2} G E_{i t} \\
& +\beta_{3} P S A V_{i t}+\beta_{4} R Q_{i t}+\beta_{5} R o L_{i t}+\beta_{6} V A_{i t}+\varepsilon_{i t} \\
\left(T A^{f} / T A\right)_{i t} & =\alpha+\sum_{j=1}^{p} \lambda_{j}\left(T A^{f} / T A\right)_{i t-j}+\beta_{1} C_{o} C_{i t}+\beta_{2} G E_{i t} \\
& +\beta_{3} P S A V_{i t}+\beta_{4} R Q_{i t}+\beta_{5} R o L_{i t}+\beta_{6} V A_{i t}+\varepsilon_{i t}
\end{aligned}
$$

Because the models, which will be analyzed, have dynamic patterns, it was preferred to use dynamic panel data method in this study. However, it is very important to use which of the alternative dynamic panel data methods. Although these kinds of models are based on the study of Anderson and Hsiao (1981), the present aspect was developed with the studies of Holtz-Eakin, Newey, and Rosen (1988) and Arellano and Bond (1991). The estimation approach, based on two stages generalized method of moment (GMM) developed by Arellano and Bond (1991), is frequently used in similar analysis. Additionally, it was also seen that system dynamic panel data approaches, which were developed by Arellano and Bover (1995) and Blundell and Bond (1998), are also used in recent studies related to the subjects of banking and insurance. System dynamic models are also based on two stages GMM, but they have superior prediction properties than the first version dynamic models.

It was thought that system dynamic models are ideal for data set which includes many sections, but has short time dimensions. Arellano-Bond (1991) method gives inclined results for this type data set. However, system dynamic models give correct results by eliminating this problem. Therefore, it should be proved that there is not second-order autocorrelation and instruments validity is provided in order to be sure that the results of this model are consistent. Thus, after Arellano-Bond test which evaluates second-order autocorrelation, Sargan test or Hansen test 
Table 2

Data Definition and Source.

\begin{tabular}{|c|c|}
\hline Variable & Definition \\
\hline$F B / T B$ & Foreign banks among total banks $(\%)^{\mathrm{a}}$ \\
\hline$T A F / T A$ & Foreign bank assets among total bank assets $(\%)^{\mathrm{a}}$ \\
\hline $\mathrm{CoC}$ & Control of corruption ${ }^{\mathrm{b}}$ \\
\hline$G E$ & Government effectiveness ${ }^{b}$ \\
\hline$P S A V$ & Political stability and absence of violence/terrorism ${ }^{b}$ \\
\hline$R Q$ & Regulatory quality ${ }^{\mathrm{b}}$ \\
\hline RoL & Rule of law ${ }^{\mathrm{b}}$ \\
\hline$V A$ & Voice and accountability ${ }^{\mathrm{b}}$ \\
\hline
\end{tabular}

a Wold Bank, Global Financial Development, 14 Sep. 2015.

b World Bank, Worlwide Governance Indicators, 25 Sep. 2015.

should be performed in order to determine the validity of instrumental variables (Roodman, 2006, 2008). Diagnostic tests should be analyzed by using these methods. Estimation process in dynamic models depends on one or two stages GMM estimators. Hence, in dynamic models, there is also an instrumental variable data set in addition to the variables in the model. These instrumental variables can be occurred form the lags of dependent variables, lags of the differences of these variables, explanatory variables and dummy variables.

\section{Data set}

The data set used in the study was provided from the internet site of World Bank. According to the World Bank's classification of the countries regarding income levels, there are 104 middle income countries. Annual data of 65 of these countries was used for the periods between 2004 and 2013. The number of total observation for each model is 4550. Because the data of American Samoa cannot be provided, we had to eliminate this country from the analysis. The data of the variables (foreign banks/total banks and the assets of foreign banks/total banks' assets) was provided from the database of World Bank Global Financial Development in 14.09.2015. On the other hand, the variables that measure the governance levels of the countries wer obtained from Bank Worldwide Governance Indicators reported in 25.09.2015. The definitions and the sources of these variables were detailed in Table 2.

The variables of "foreign banks among total banks" and "foreign bank assets among total bank assets" are used in this study to represent the situation of foreign ownership of the banks. In addition to them, 6 different variables are also taken into the consideration to see the effect of corporate governance that are "control of corruption", "government effectiveness", "political stability and absence of violence/terrorism", "regulatory quality", "rule of law" and "voice and accountability". As it can be understood that all these variables give information about the governance situation in a country.

\section{Results}

First of all, the structure of the variables was evaluated. Within this context, descriptive statistics, correlation coefficients and stationary testing were analyzed. The descriptive statistics of the variables were presented in Table 3. It was defined that all variables were not distributed normally. 
Table 3

Descriptive statistics.

\begin{tabular}{lllllllll}
\hline & $F B / T B$ & $T A^{f} / T A$ & $C o C$ & $G E$ & $P S A V$ & $R Q$ & $R o L$ & $V A$ \\
\hline Mean & 43.4200 & 34.5677 & -0.1022 & -0.1629 & -0.1531 & -0.1623 & -0.1596 & -0.0744 \\
Median & 42.5000 & 25.0000 & -0.4550 & -0.4500 & -0.1900 & -0.3200 & -0.4900 & -0.0300 \\
Maximum & 91 & 100 & 2.46 & 2.22 & 1.94 & 1.99 & 1.99 & 1.76 \\
Minimum & 0 & 0 & -1.73 & -1.87 & -2.81 & -2.34 & -1.79 & -2.22 \\
Std. Dev. & 24.1782 & 31.4887 & 1.0417 & 0.9749 & 1.0147 & 1.0102 & 1.0031 & 0.9527 \\
Skewness & 0.0167 & 0.5259 & 0.8311 & 0.6761 & -0.1693 & 0.3774 & 0.6255 & 0.0107 \\
Kurtosis & 1.9916 & 1.8674 & 2.6184 & 2.5846 & 2.1556 & 2.4069 & 2.2521 & 2.2449 \\
Jarque-Bera & 27.5727 & 64.7102 & 78.7717 & 54.1959 & 22.4177 & 24.9556 & 57.5349 & 15.4551 \\
& {$[0.000]$} & {$[0.000]$} & {$[0.000]$} & {$[0.000]$} & {$[0.000]$} & {$[0.000]$} & {$[0.000]$} & {$[0.000]$} \\
\hline
\end{tabular}

Table 4

Correlation matrix.

\begin{tabular}{|c|c|c|c|c|c|c|c|c|}
\hline & $F B / T B$ & $T A^{f} / T A$ & $\mathrm{CoC}$ & $G E$ & PSAV & $R Q$ & $R o L$ & $V A$ \\
\hline$F B / T B$ & 1.0000 & & & & & & & \\
\hline$T A^{f} / T A$ & 0.7346 & 1.0000 & & & & & & \\
\hline $\mathrm{CoC}$ & 0.0873 & 0.1391 & 1.0000 & & & & & \\
\hline$G E$ & 0.1244 & 0.1496 & 0.9474 & 1.0000 & & & & \\
\hline PSAV & 0.0591 & 0.1581 & 0.7631 & 0.7196 & 1.0000 & & & \\
\hline$R Q$ & 0.0971 & 0.1127 & 0.8784 & 0.9234 & 0.6294 & 1.0000 & & \\
\hline$\widehat{R o L}$ & 0.1048 & 0.1526 & 0.9513 & 0.9364 & 0.8046 & 0.8816 & 1.0000 & \\
\hline$V A$ & 0.0702 & 0.1499 & 0.8025 & 0.7973 & 0.6919 & 0.8013 & 0.8439 & 1.0000 \\
\hline
\end{tabular}

Despite the fact that $P S A V_{i t}$ is negatively skewed, it was seen that all other variables are positively skewed. Moreover, it was determined that the skewness of all variables is within normal limits.

In addition to this aspect, the relationship among the variables was also evaluated with the help of correlation coefficient matrix. According to the correlation coefficient values depicted in Table 4, it was identified that corporate governance predictors have strong relationship (more than $70 \%$ more) with each other. On the other side, it was also determined that governance variables have $6 \%-12 \%$ correlation with $(F B / T B)_{i t}$ and $11 \%-15 \%$ correlation with $\left(T A^{f} / T A\right)_{i t}$.

Furthermore, with respect to the stationary analysis of the variables, " $t$ " test developed by Levin, Lin, and Chu (2002), "W" test developed by, Im, Pesaran and Shin (2003) and "ADFFisher" panel unit root tests developed by Choi (2001) were used in the study. The results of these tests were given in Table 5. As a result of this analysis, it was concluded that all variables are stationary in their level values.

In the second part of the analysis, two stages system dynamic panel data models based on the studies of Arellano and Bover (1995) and Blundell and Bond (1998) were used. Estimation results of this analysis were emphasized in Table 6. In this analysis, the models of (3) and (4) were predicted respectively. Because the number of observation per section is limited, only first differences of dependent variables were considered in the analysis. In prediction process, the variables, which have statistically insignificant values, were eliminated from the original models ((3) and (4)). While making this analysis, we reached refined models that give only meaningful parameter values. In addition to this situation, both fundamental models and the most significant models were given in Table 6. 
Table 5

Panel unit root tests.

\begin{tabular}{|c|c|c|c|c|c|c|c|c|c|c|c|c|}
\hline & \multicolumn{3}{|c|}{$F B / T B$} & \multicolumn{3}{|c|}{$T A^{f} / T A$} & \multicolumn{3}{|c|}{$\mathrm{CoC}$} & \multicolumn{3}{|c|}{$G E$} \\
\hline & Statistic & $p$ value & e $\mathrm{Lag}^{\mathrm{c}}$ & Statistic & $p$ value & $\mathrm{Lag}^{\mathrm{c}}$ & Statistic & $p$ value & $\mathrm{Lag}^{\mathrm{c}}$ & Statistic & $p$ value & $\mathrm{Lag}^{\mathrm{c}}$ \\
\hline $\begin{array}{l}\text { Levin, Lin } \\
\text { and Chu t }\end{array}$ & -194.2820 & $\begin{array}{ll}0 & 0.0000\end{array}$ & 1 & -30.9525 & 0.0000 & 1 & -14.6914 & 0.0000 & 1 & -19.2137 & 0.0000 & 1 \\
\hline $\begin{array}{c}\text { Im, Pesaran } \\
\text { and Shin } \\
\text { W-stat }\end{array}$ & -30.2953 & 0.0000 & 1 & -10.6278 & 0.0000 & 1 & -6.5933 & 0.0000 & 1 & -6.2059 & 0.0000 & 1 \\
\hline $\begin{array}{l}\text { ADF - } \\
\text { Fisher } \\
\text { Chi- } \\
\text { square }^{b}\end{array}$ & 304.3140 & 0.0000 & 1 & 303.3100 & 0.0000 & 1 & 279.3450 & 0.0000 & 1 & 266.6110 & 0.0000 & 1 \\
\hline \multirow{3}{*}{$\begin{array}{l}\text { PP - Fisher } \\
\quad \text { Chi- } \\
\text { square }^{b}\end{array}$} & 282.0800 & 0.0000 & 1 & 278.8880 & 0.0000 & 1 & 265.1600 & 0.0000 & 1 & 222.1610 & 0.0000 & 1 \\
\hline & \multicolumn{3}{|c|}{ PSAV } & \multicolumn{3}{|c|}{ RQ } & \multicolumn{3}{|c|}{ RoL } & \multicolumn{3}{|c|}{ VA } \\
\hline & Statistic & $p$ value & $\mathrm{Lag}^{\mathrm{c}}$ & Statistic & $p$ value & $\mathrm{Lag}^{\mathrm{c}}$ & Statistic & $p$ value & $\mathrm{Lag}^{\mathrm{c}}$ & Statistic & $p$ value & $\mathrm{Lag}^{\mathrm{c}}$ \\
\hline $\begin{array}{l}\text { Levin, Lin } \\
\text { and Chu } \mathrm{t}^{\mathrm{a}}\end{array}$ & -6.7702 & 0.0000 & 1 & -13.8715 & 0.0000 & 1 & -12.4439 & 0.0000 & 1 & -13.6670 & 0.0000 & 1 \\
\hline $\begin{array}{c}\text { Im, Pesaran } \\
\text { and Shin } \\
\text { W-stat }\end{array}$ & -2.0158 & 0.0219 & 1 & -4.3863 & 0.0000 & 1 & -5.1215 & 0.0000 & 1 & -6.5602 & 0.0000 & 1 \\
\hline $\begin{array}{l}\text { ADF - } \\
\text { Fisher } \\
\text { Chi- } \\
\text { square }^{b}\end{array}$ & 186.8960 & 0.0008 & 1 & 219.3950 & 0.0000 & 1 & 242.1450 & 0.0000 & 1 & 281.8920 & 0.0000 & 1 \\
\hline $\begin{array}{l}\text { PP - Fisher } \\
\text { Chi- } \\
\text { square }^{b}\end{array}$ & 194.1880 & 0.0002 & 1 & 194.3720 & 0.0001 & 1 & 240.5320 & 0.0000 & 1 & 289.0190 & 0.0000 & 1 \\
\hline
\end{tabular}

a Null hypothesis assumes common unit root process.

b Null hypothesis assumes individual unit root process.

${ }^{c}$ Lag length selection based on Shwarz information criterion.

It was defined that all estimations passed diagnostic tests. Additionally, Wald tests show that the significance of the models is high. Furthermore, the results of Sargan test, which evaluates the validity of instrumental variables, state that the choice of these variables is correct for all models. Another condition for the validity of the models is that residuals should not have second order $(A R(2))$ autocorrelation problem. Arellano-Bond test is used for this situation. This test evaluates the first order $(A R(1))$ and second order $(A R(2))$ autocorrelation of the first difference of the residuals. Thus, it is expected that there is not at least second order autocorrelation in the first difference of the residuals in this test. According to the results of the analysis, it was identified that there is not second order autocorrelation in all models. Therefore, it can be said that GMM estimations are efficient.

The estimation results of the models (3) and (4) explain that the lags of the variables take significant and high parameter values. In other words, there is high persistency in foreign bank operations. According to the estimation results of model (3), it was defined that governance variables except $C o C_{i t}$ and $V A_{i t}$ are significant. Furthermore, it was also seen that the variables 
Table 6

System dynamic panel data estimations.

\begin{tabular}{|c|c|c|c|c|c|c|c|c|}
\hline & \multicolumn{4}{|c|}{$F B / T B$} & \multicolumn{4}{|c|}{$T A / T A$} \\
\hline & Coeff. & $z$ test & Coeff. & $z$ test & Coeff. & $z$ test & Coeff. & $z$ test \\
\hline \multirow{2}{*}{$\begin{array}{l}F B / T B(-1) \\
T A^{f} / T A(-1)\end{array}$} & 0.867 & $83.450^{* *}$ & 0.870 & $80.900^{* *}$ & & & & \\
\hline & & & & & 0.488 & $102.210^{* *}$ & 0.488 & $127.840^{* * *}$ \\
\hline $\mathrm{CoC}$ & -0.739 & -0.950 & & & 0.431 & 0.760 & 4.745 & $4.650^{\text {** }}$ \\
\hline$G E$ & 5.651 & $10.030^{* *}$ & 5.797 & $11.020^{* *}$ & -0.962 & -0.890 & & \\
\hline$P S A V$ & -8.605 & $-10.160^{* *}$ & -8.786 & $-10.160^{* *}$ & 10.998 & $12.030^{* *}$ & 10.295 & $11.720^{* *}$ \\
\hline$R Q$ & -1.353 & $-4.000^{* *}$ & -1.310 & $-3.200^{* *}$ & -7.320 & $-9.470^{* *}$ & -7.362 & $-10.800^{* * *}$ \\
\hline RoL & 1.992 & $2.090^{*}$ & 2.175 & $2.440^{*}$ & -6.697 & $-4.980^{* *}$ & -7.063 & $-5.600^{* * *}$ \\
\hline$V A$ & 1.124 & 1.570 & & & 4.552 & $4.670^{* *}$ & & \\
\hline \multirow{2}{*}{$\begin{array}{l}c \\
\text { Wald tests }\end{array}$} & 6.306 & $9.860^{* * *}$ & 6.089 & $8.920^{* * *}$ & 18.229 & $29.220^{* *}$ & 18.097 & $28.180^{\text {*** }}$ \\
\hline & & & & & & & & \\
\hline \multirow{2}{*}{ Chi square } & 21734.9 & & 19713.77 & & 38478.2 & & 40128.57 & \\
\hline & {$[0.0000]$} & & {$[0.0000]$} & & {$[0.0000]$} & & {$[0.0000]$} & \\
\hline \multicolumn{9}{|l|}{ Sargan tests } \\
\hline \multirow[t]{4}{*}{ Chi square } & 51.6109 & & 51.39876 & & 49.95764 & & 49.75472 & \\
\hline & [0.1726] & & {$[0.1779]$} & & [0.2164] & & {$[0.2223]$} & \\
\hline & \multicolumn{8}{|c|}{ Arellano-Bond tests } \\
\hline & $z$ test & $p$ value & $z$ test & $p$ value & $z$ test & $p$ value & $z$ test & $p$ value \\
\hline$A R(1)$ & -1.8100 & 0.0703 & -1.8159 & 0.0694 & -1.5338 & 0.1251 & -1.5332 & 0.1252 \\
\hline$A R(2)$ & -1.0206 & 0.3075 & -1.0116 & 0.3117 & 1.1005 & 0.2711 & 1.0998 & 0.2714 \\
\hline
\end{tabular}

\footnotetext{
* Show $z$ test in the significant level $5 \%$.

** Show $z$ test in the significant level $1 \%$.
}

of $G E_{i t}$ and $R o L_{i t}$ affect dependent variables positively whereas $P S A V_{i t}$ and $R Q_{i t}$ have a negative effect on it. These results mean that the ratio of foreign banks to the total banks goes up when effectiveness of the government increases and legal infrastructure becomes strong. On the other hand, increase in political stability and strict regulation lead to decline in the number of foreign banks.

In addition to this issue, the estimation results of the model (4) show that $G E_{i t}$ and $V A_{i t}$ are insignificant. With respect to the significant variables, the coefficients of $R Q_{i t}$ and $R o L_{i t}$ are negative while $C o C_{i t}$ and $P S A V_{i t}$ have positive coefficients. It was determined that the importance of foreign banks in the market regarding the size of total assets increases when there is low corruption and high political stability. Nevertheless, it was also identified that improvements in legal infrastructure and strict regulation causes foreign banks to decrease their asset size in these countries.

According to the analysis results, it was seen that the variables of $C o C_{i t}, P S A V_{i t}$ and $R o L_{i t}$ give contradictory results in models (3) and (4) as for the sign of the coefficients. It was thought that the results of model (4) are more meaningful and consistent with respect to the effects of the first two variables on dependent variables. It is understandable that the countries, in which there is increase in the fighting against corruption and political stability, become attractive for foreign banks. However, model (3) gave more reasonable results regarding $\mathrm{RoL}_{\mathrm{it}}$ because foreign banks pay attention to legal infrastructure. On the other side, it was found that $\mathrm{VA}_{\mathrm{it}}$ is insignificant in 
both models. This aspect shows that foreign banks are not affected the level of transparency and accountability in the countries.

In conclusion, it was identified that foreign bank operations are influenced significantly by the governance environment of the countries. Within this context, it was determined that corruption, politic stability, legal system and flexibility in legal regulations are important factors for this situation. In addition to them, it was also seen that foreign bank operations depend on the past events strongly. Therefore, it can be concluded that foreign banks have strong connections to the markets in which they operated for a long time and they satisfy the expectations regarding governance in these markets.

\section{Conclusion}

In this study, we evaluated the relationship between foreign bank operations and corporate governance levels in developing countries. Annual data of 65 developing countries which have middle income level for the periods between 2004 and 2013 was used. Moreover, we made two stages system dynamic panel data estimation in this study. According to the results of this analysis, it was identified that there is a strong relationship between operations of foreign banks and governance levels of the countries. It was determined that foreign bank operations are mostly affected by the factors of corruption, political stability, rule of law and flexibility in legal regulations. Foreign bank operations are stronger in the countries that have low poverty, high political stability and efficient legal infrastructure rather than other countries. However, it was also defined that foreign bank operations are affected by strict legal regulation negatively. This situation explains that foreign banks prefer to enter into the countries that have flexible legal regulations.

Foreign banks are important chances for developing countries in order to have higher economic growth. Therefore, influencing factors that affect the decisions of the foreign banks are very significant. This study provides empirical support to the relationship between corporate governance levels of developing countries and foreign ownership levels of the banks. While considering the results of this study, the authorities of these countries can take necessary actions in order to attract foreign banks.

\section{Appendix.}

Table A1. 
Table A1

Middle income countries. ${ }^{a}$

\begin{tabular}{|c|c|c|c|}
\hline Albania & Egypt, Arab Rep. & Malaysia & Serbia \\
\hline Algeria & El Salvador & Maldives & Solomon Islands \\
\hline Angola & Fiji & Marshall Islands & South Africa \\
\hline Armenia & Gabon & Mauritania & Sri Lanka \\
\hline Azerbaijan & Georgia & Mauritius & St. Lucia \\
\hline Bangladesh & Ghana & Mexico & St. Vincent and the Grenadines \\
\hline Belarus & Grenada & Micronesia, Fed. Sts. & Sudan \\
\hline Belize & Guatemala & Moldova & Suriname \\
\hline Bhutan & Guyana & Mongolia & Swaziland \\
\hline Bolivia & Honduras & Montenegro & Syrian Arab Republic \\
\hline Bosnia and Herzegovina & India & Morocco & Tajikistan \\
\hline Botswana & Indonesia & Myanmar & Thailand \\
\hline Brazil & Iran, Islamic Rep. & Namibia & Timor-Leste \\
\hline Bulgaria & Iraq & Nicaragua & Tonga \\
\hline Cabo Verde & Jamaica & Nigeria & Tunisia \\
\hline Cameroon & Jordan & Pakistan & Turkey \\
\hline China & Kazakhstan & Palau & Turkmenistan \\
\hline Colombia & Kenya & Panama & Tuvalu \\
\hline Congo, Rep. & Kiribati & Papua New Guinea & Ukraine \\
\hline Costa Rica & Kosovo & Paraguay & Uzbekistan \\
\hline Cote d'Ivoire & Kyrgyz Republic & Peru & Vanuatu \\
\hline Cuba & Lao PDR & Philippines & Vietnam \\
\hline Djibouti & Lebanon & Romania & West Bank and Gaza \\
\hline Dominica & Lesotho & Samoa & Yemen, Rep. \\
\hline Dominican Republic & Libya & Sao Tome and Principe & Zambia \\
\hline Ecuador & Macedonia, FYR & Senegal & \\
\hline
\end{tabular}

${ }^{a}$ Countries have been selected by the World Bank income level classification. American Samoa was not considered because of insufficient data.

\section{References}

Acrey, J. C., McCumber, W. R., \& Nguyen, T. H. T. (2011). CEO incentives and bank risk. Journal of Economics and Business, 63, 456-471. http://www.sciencedirect.com/science/article/pii/S0148619510000640

Aebi, V., Sabato, G., \& Schmid, M. (2012). Risk management, corporate governance, and bank performance. Journal of Banking and Finance, 36, 3213-3226. http://www.sciencedirect.com/science/article/pii/S0378426611003104

Anderson, T. W., \& Hsiao, C. (1981). Estimation of dynamic models with error components. Journal of American Statistical Association, 76(375), 598-606. http://www.tandfonline.com/doi/abs/10.1080/01621459.1981.10477691

Anginer, D., Demirguc-Kunt, A., Huizinga, H., \& Ma, K. (2016). How does corporate governance affect bank capitalization strategies? Journal of Financial Intermediation (in press) DOI: https://doi.org/10.1016/j.jfi.2015.12.002.

Arellano, M., \& Bond, S. (1991). Some tests of specification for panel data: Monte Carlo evidence and an application to unemployment equations. Review of Economic Studies, 58, 277-297. http://restud.oxfordjournals.org/ content/58/2/277. short

Arellano, M., \& Bover, O. (1995). Another look at the instrumental variable estimation of error-components models. Journal of Econometrics, 68(1), 29-51. http://www.sciencedirect.com/science/article/pii/030440769401642D

Arun, T. G., \& Turner, J. D. (2004). Corporate governance of banks in developing economies: Concepts and issues. Corporate Governance, 12(3), 371-377. http://dx.doi.org/10.1111/j.1467-8683.2004.00378.x

Barakat, A., \& Hussainey, K. (2013). Bank governance, regulation, supervision, and risk reporting: Evidence from operational risk disclosures in European banks. International Review of Financial Analysis, 30, $254-273$. http://www.sciencedirect.com/science/article/pii/S1057521913000823

Barry, T. A., Lepetit, L., \& Strobel, F. (2015). Bank ownership structure, lending corruption and regulatory environment. Journal of Comperative Economics (in press). http://www.sciencedirect.com/science/article/pii/S0147596715000773 
Berger, A. N., Klapper, L. F., \& Udell, G. F. (2000). The ability of banks to lend to informationally opaque small businesses. Washington, DC, mimeo: World Bank. http://dx.doi.org/10.1016/S0378-4266(01)00189-3

Blundell, R., \& Bond, S. (1998). Initial conditions and moment restrictions in dynamic panel data models. Journal of Econometrics, 87(1), 115-143. http://www.sciencedirect.com/science/article/pii/S0304407698000098

Caprio, G., \& Levine, R. (2002). Corporate governance in finance: Concepts and international observations. World Bank Paper, http://go.worldbank.org/9HNQUH32G0). URL: http://www.sciencedirect.com/science/ article/pii/S1572308912000575

Chen, M., Jeon, B. N., Wang, R., \& Wu, J. (2015). Corruption and bank risk-taking: Evidence from emerging economies. Emerging Markets Review, 24, 122-148. http://www.sciencedirect.com/science/article/pii/S1566014115000400

Chen, S.-H., \& Liao, C.-C. (2011). Are foreign banks more profitable than domestic banks? Home- and host-country effects of banking market structure, governance, and supervision. Journal of Banking and Finance, 35, 819-839. http://www.sciencedirect.com/science/article/pii/S0378426610004358

Chitan, G. (2012). Corporate governance and bank performance in the romanian banking sector. Procedia - Economics and Finance, 3, 549-554. http://www.sciencedirect.com/science/article/pii/S2212567112001943

Choi, I. (2001). Unit root tests for panel data. Journal of International Money and Finance, 20, 249-272. http://www.sciencedirect.com/science/article/pii/S2212567112001943

Claessens, S., Demirguc-Kunt, A., \& Huizanga, H. (2000). The role of foreign banks in domestic banking systems. In S. Claessens, \& M. Jansen (Eds.), The internationalization of financial services: Issues and lessons for developing countries (pp. 117-138). Boston, MA: Kluwer Academic Press.

Claessens, S., Demirguc-Kunt, A., \& Huizinga, H. (1998). How does foreign entry affect the domestic banking market? Policy Research Working Paper Series, No. 1918. The World Bank.

Clarke, G., Cull, R., Martinez Peria, M. S., \& Sánchez, S. M. (2001). Bank lending to small businesses in Latin America: Does bank origin matter? Washington, DC, mimeo: World Bank.

Cull, R., Li, W., Sun, B., \& Xu, L. C. (2015). Government connections and financial constraints: Evidence from a large representative sample of chinese firms. Journal of Corporate Finance, 32, $271-294$. http://www.sciencedirect.com/science/article/pii/S092911991400128X

Demirguc-Kunt, A., \& Detragiache, E. (1998). The determinants of banking crises in developing and developed countries. IMF Staff Papers, 45(1), 81-109.

Drew, S. A., Kelley, P. C., \& Kendrick, T. (2006). CLASS: Five elements of corporate governance to manage strategic risk. Business Horizons, 49, 127-138. http://www.sciencedirect.com/science/article/pii/S0007681305001011

Farhlenbrach, R., \& Stulz, R. M. (2011). Bank CEO incentives and the credit crisis. Journal of Financial Economics, 99 , 11-26. http://www.sciencedirect.com/science/article/pii/S0304405X10001868

Ho, P.-H., Lin, C.-Y., \& Tsai, W.-C. (2015). Effect of country governance on bank privatization performance. International Review of Economics and Finance (in press). URL: http://www.sciencedirect.com/science/ article/pii/S1059056015001781

Holtz-Eakin, D., Newey, W., \& Rosen, H. S. (1988). Estimating vector autoregressions with panel data. Econometrica, 56(6), 1371-1395. http://www.jstor.org/stable/1913103?seq=1\#page_scan_tab_contents

Im, K. S., Pesaran, M. H., \& Shin, Y. (2003). Testing for unit roots in heterogeneous panels. Journal of Econometrics, 115(1), 53-74. http://www.sciencedirect.com/science/article/pii/S0304407603000927

Iqbal, J., Strobl, S., \& Vahamaa, S. (2015). Corporate governance and systemic risk of financial institutions. Journal of Economics and Business, 82, 42-61. http://www.sciencedirect.com/science/article/pii/S0148619515000351

Jackowicz, K., Kowalewski, O., \& Kozlowski, L. (2013). The influence of political factors on commercial banks in central european countries. Journal of Financial Stability, 9, 759-777. http://www.sciencedirect.com/ science/article/pii/S1572308912000484

Lassoued, N., Sassi, H., \& Attia, M. B. R. (2016). The impact of state and foreign ownership on banking risk: Evidence from the MENA countries. Research in International Business and Finance, 36, 167-178. http://www.sciencedirect.com/science/article/pii/S0275531915300209

Lensink, R., Meesters, A., \& Naaborg, I. (2008). Bank efficiency and foreign ownership: Do good institutions matter? Journal of Banking and Finance, 32, 834-844. http://dx.doi.org/10.1016/j.jbankfin.2007.06.001

Levin, A., Lin, C.-F., \& Chu, J. C. (2002). Unit root tests in panel data: Asymptotic and finite-sample properties. Journal of Econometrics, 108(1), 1-24. http://www.sciencedirect.com/science/article/pii/S0304407601000987

Levine, R. (1999). Foreign bank entry and capital control liberalization: Effects on growth and stability. University of Minnesota, mimeo.

Levine, R. (2004, September). The corporate governance of banks: A concise discussion of concepts and evidence World Bank Policy Research Working Paper No. 3404. 
Li, L., \& Song, F. M. (2013). Do bank regulations affect board independence? A cross-country analysis. Journal of Banking and Finance, 37, 2714-2732. http://www.sciencedirect.com/science/article/pii/S0378426613001696

Lin, C.-Y, Ho, P.-H., Shen, C.-H., \& Wang, Y.-C. (2016). Political connection, government policy, and investor trading: Evidence from an emerging market. International Review of Economics and Finance, 42, $153-166$. http://www.sciencedirect.com/science/article/pii/S1059056015001537

Luo, Y. (2015). CEO power, ownership structure and pay performance in Chinese banking. Journal of Economics and Business, 82, 3-16. http://www.sciencedirect.com/science/article/pii/S0148619515000211

Masciandaro, D., Pansini, R. V., \& Quintyn, M. (2013). The economic crisis: Did supervision architecture and governance matter? Journal of Financial Stability, 9, 578-596. http://www.sciencedirect.com/science/ article/pii/S1572308912000630

Miklaszewska, E., \& Mikolajczyk, K. (2011). Foreign banks in central eastern europe: Impact of foreign governance on bank performance. In P. Molyneux (Ed.), Bank performance, risk and firm financing (pp. 55-82). Hampshire, England: Palgrave Macmillan Studies in Banking and Financial Institutions.

Min, B. S., \& Bowman, R. G. (2015). Corporate governance, regulation and foreign equity ownership: Lessons from Korea. Economic Modelling, 47, 145-155. http://www.sciencedirect.com/science/article/pii/S0264999315000474

Oh, C. H., Park, J.-H., \& Ghauri, P. N. (2013). Doing right, investing right: Socially responsible investing and shareholder activism in the financial sector. Business Horizons, 56, 703-714. http://www.sciencedirect.com/science/ article/pii/S0007681313001043

Özelge, S., \& Saunders, A. (2012). The role of lending banks in forced CEO turnovers. Journal of Money, Credit and Banking, 44(4), 631-659.

Peek, J., \& Rosengren, E. S. (2000, Septmber/October). Implications of the globalization of the banking sector: The Latin American experience. New England Economic Review, 45-62.

Qian, M., \& Yeung, B. Y. (2015). Bank financing and corporate governance. Journal of Corporate Finance, 32, 258-270. http://www.sciencedirect.com/science/article/pii/S0929119914001229

Roodman, D. (2006, December). How to Do xtabond2: An introduction to "difference" and "system" GMM in stata Center for Global Development Working Paper No. 103. http://papers.ssrn.com/sol3/papers.cfm?abstract_id=982943

Roodman, D. (2008, May). A note on the theme of too many instruments Center for Global Development Working Paper No. 125.

Shailer, G. E. (2004). Introduction to corporate governance in Australia. Pearson Education Australia.

Shen, C.-H., Lin, C.-Y., \& Wang, Y.-C. (2015). Do strong corporate governance firms still require political connection, and vice versa? International Review of Economics and Finance, 39, 107-120. http://www.sciencedirect.com/science/article/pii/S1059056015001070

Zagorchev, A., \& Gao, L. (2015). Corporate governance and performance of financial institutions. Journal of Economics and Business, 82, 17-41. http://www.sciencedirect.com/science/article/pii/S0148619515000223 